Sid. Time Micr. Red. $\triangle \delta$

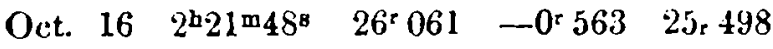

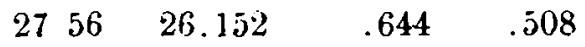

$234 \quad 12 \quad 26.196 \quad-0.727 \quad .469$

$2 \overline{5507}+0.0074$

In order to secure a trustwortby determination of the solar parallax by Professor Galle's method it is evident that the utmost care must be given to the micrometrical measurements, both at the northern and at the southern observatories. The angle at the planet which determines its distance from the earth, and hence the parallax, is made up of the two angles formed by the lines drawn from the planet to the center of the earth and to the mean positions of the northern and southern observatories, and it one of these angles is unccrtain the whole angle is also. As to Professor Galle's method of rejecting observations and of deducing the probable error of his result there will bo varions opinious; but it will be agreed, I think, that he has unade an ingenious application of Mr. Stone's Criterion.
It is interesting to compare the discordances between the different observatories. Thus in 1872 the single coincident observation of Phocea made at Lund and at Dublin gives the discordance, Lund - Dublin $=-0$ "02; but in the Flora observations of 1873 there are the following discordances between these observatories.

$-0^{\prime \prime} 055 ;+00^{\prime \prime} 080 ;+0^{\prime \prime} 330 ;-0^{\prime \prime} 816 ;+0 " 965$.

Whatever may be the source of these differences between skillful observers they tend to throw doubt on the reality of the small quantities that are found in the investigations of stellar parallax. For although a part of these differences probably arises from peculiarities of observer and instrument, yet since the parallax of a star has a period of a year, and during this time the observer, telescope and micrometer, must act under various conditions of temperature, atmosphere, etc., the determination of such small angles may be doubtful no matter what their computed probable errors may be.

Washington. 1875, Aug. 31 .

A. Hall.

\title{
Entdeckung zweier neuen Planeten.
}

(Bulletin International Nr. 272)

Le 21. Septembre dernier, Mr. Perrotio a observé à l'observatoire de Taulouse une planète de $13^{\text {tam }}$ grandeur, qu'il a pu suivre les jours suivants; voici ses coordonnées approchées:

Dates 1875, Septembre 21

30. Septembre 1875 .

T.M.

$8^{\mathrm{h}}$
8
8
8

AR. $23^{\mathrm{h}} 16^{\mathrm{m}} 8^{\mathrm{B}}$

231518

231428

$23 \quad 13 \quad 36$
Décl.

$-5^{0} 12^{\prime}$

$-5.18$

$-5.25$

$-5.30$

(Bulletin International Nr. 293)

Planet by $W$ atson on zero north six fifty four tenth daily motion south five.

Washington, 19. October 1875.

Joseph Henry, Smithsonian Institution.

\section{Anzeige.}

Im Verlag von Wilhelm Mauke in Loipzig ist erschienen:

General-Register der Bände LXI bis LXXX der Astr. Nachr. Ausgearbeitet von $C$. $F$. $W$. Peters, Dr. phil., Observator der Sternwarte in Kiel. Leipzig 1875.

\section{In halt:}

Zu Nir. 2061. G. Strasser. Todesanzeige. 321. - A. Hall. Observations made with the 26 -inch Equatorial of the U. S. Naval Observatory, at Washington, in 1875. 321. - A. Hall. On the Delermination of the Hass of Mars. 327. - A. Mall. On the Washington Observations of Flora in 1873. 333. - Entdeckuns zweier neuen Planeten. 335. - Anzeige. 335. 